\title{
INTEGRATION OF TRANSHUMANT PASTORALISM AND IRRIGATED AGRICULTURE IN SEMIARID EAST AFRICA
}

\author{
Jon D. Unruh \\ McGill University.
}

\begin{abstract}
Agricultural development projects in the fertile and most well watered areas of arid and semiarid Africa usually deny access to nomadic pastoralists whose production system and livelihood depend upon such areas in the dry season and during frequent droughts. The result can be degradation of range resources through overgrazing, and greater vulnerability of pastoralists.

Recent calls for "compatible" land use schemes or "nonexclusionary" agricultural development projects in the context of pastoralist transhumance, suggest allowing pastoralists structured access to project sites in the dry season in order to utilize forage and water supplies. This paper examines the capacity of an irrigation scheme to support the seasonal influx of transhumant livestock in dry seasons of varying severity. The livestock carrying capacity of the existing mosaic of land use patterns and practices is used in the determination of the proportional areas of land use needed to absorb large seasonal concentrations of livestock.
\end{abstract}

Key Words: Transhmant pastoralism, semi-arid, east Africa, irrigation, land use, carrying capacity, Somalia

\section{INTRODUCTION}

The seasonal concentration and dispersal of nomadic pastoralists and their herds to and from dry season forage and water supplies is a general phenomenon observed in arid and semiarid environments throughout the world. Approximately one hird of the earth's land surface is comprised of arid and semiarid ecosystems which support over 30 million people who are primarily pastoralists (Sandford, 1976). Transhumant herding is an adaptation to ecosystems in which the availability of forage and water are critical parameters (Darling and Farvar, 1972; Box, 1971; Handulle and Gay, 1987; Campell, 1981; Western, 1975; Sandford, 1982; Breman et al., 1979; Scudder, 1989; 
McCabe, 1987). In fact it is the quantity of dry season forage within reach of dry season watering points that is the mechanism that controls transhumant populations of livestock; and when this forage is depleted the result can be large livestock dieoffs and rapid sales (Sandford, 1983; Gulliver, 1975; Lewis, 1975). The production system of pastoralists and of the livestock industry in many arid and semiarid countries largely hinges upon access to dry season forage and water supplies.

Agricultural development projects and the extension of cultivation in the arid and semiarid regions of Africa usually take place in the most fertile and well watered areas, often to the exclusion of other uses. Such areas traditionally have provided dry season grazing and watering for herds belonging to transhumant pastoralists (Scudder, 1989; Frantz, 1975; Campbell, 1981, Stiles, 1983; Swift, 1977; Krader, 1959; Talbot, 1972; Sandford, 1982, 1983; Davis, 1971). Exclusion of transhumant herds can lead to a number of problems in addition to damaging the livestock industry and the livelihood of pastoral peoples. Unavailable forage in one part of the yearly travels of livestock herders can have disastrous effects on other areas, because the herders are then forced to use range resources that are already marginal (Riddell, 1982; Johnson, 1986; Riney, 1979). Rangeland degradation occurs as the carrying capacity of these areas is surpassed due to overgrazing caused by a higher dry season livestock density (Box, 1968, 1971; Salzman, 1986; Stiles, 1983; Sanford, 1982; Johnson, 1986; Lamprey, 1983; Little, 1984; Lewis, 1975; Chatterton and Chatterton, 1984). Davis (1971) states that the restricted movements forced upon nomadic pastoralists and the subsequent overgrazing and decline in range productivity recurs "continuously" in reports on east African rangeland conditions. Such degradation contributes to desertification and local climate change (Otterman, 1974; Ripley, 1976; Reck, 1989) and places nomadic pastoralists and their herds in a position of increased vulnerability to drought, with the subsequent results being destitution of nomadic populations and large expenditures for famine relief and refugee programs (Oba, 1985; Frantz, 1975; McCabe, 1987; Toulmin, 1985; Little, 1984; Campbell, 1981; Lewis, 1975). Land use conflicts in river basin and floodplain areas increase as degradation of rangelands, growing populations, and greater pressure on these areas to produce food, cause increased competition for land and water resources.

Inadequately designed agricultural development projects in Africa have, in the past, led to severe environmental and social 
problems (Scudder, 1989; Bennett, 1984; Mohamed, 1981; Speth, 1985; Walsh, 1984). Such experiences bring into question the viability of designs which induce drastic change very quickly on existing modes of land use. In-place subsistence production systems function because farmer familiarity and knowledge of them enables established exchange relationships to operate within the variability and constraints of the local ecology. These systems usually already contain the complicated and longevolving risk reduction and coping strategies necessary for survival in difficult environments. Given the unpredictable and severe occurrences of drought in Africa and the complicated, location specific nature of land tenure and other social - land interactions, it can be very difficult to replace such interactions or expect them to quickly re-evolve in the wake of project implementation. Existing land use patterns and practices have already experienced and dealt with in some fashion problems pertaining to: land transactions, land fragmentation, culturally determined preferences for food production, ethnic relationships, and land management options given the reigning socio-political constraints and opportunities. Such in-place characteristics are a part of relationships and arrangements that tie specific localities with wider areas. Designs which disrupt these linkages will have impacts on other areas as well.

Recent proposals for "compatible" or "nonexclusionary" land use schemes or development projects in the context of nomadic pastoralism suggest allowing transhumant herds structured access to project sites in order to utilize available dry season forage and water supplies (Campbell, 1981; Handulle and Gay, 1987; RMR, 1984). However these suggestions have not yet proceeded beyond general qualitative recommendations. This paper makes a quantitative evaluation of the existing capacity of an irrigated area to support a large influx of transhumant herds, in dry seasons of varying severity. This approach concerns the determination of the proportional area under the existing mosaic of land uses that is needed to absorb a large seasonal concentration of livestock.

\section{Location}

\section{THE STUDY AREA}

The study area is located in southern Somalia, in the lower Shabelle flood plain, approximately $100 \mathrm{~km}$ south of the capital, 
Mogadishu, and $11 \mathrm{~km}$ inland from the coastal city of Merca (Figure 1). It is situated between $44030^{\prime}$ and 450 east longitude, and 10 30' and 20 degrees north latitude. The area is characterized by fairly level topography, fine textured soils, and a tropical semiarid climate (TAMS, 1986). Situated adjacent to the shabelle river, the site covers approximately 8,500 variably irrigated hectares. It is bordered by coastal sand dunes to the east and south and an old river channel to the north and west (Figure 2).

\section{Environment}

Average annual precipitation for the area is $400 \mathrm{~mm} /$ year, ranging from 282.3 to $736.0 \mathrm{~mm} /$ year (Ministry of Agriculture Meteorological Service, 1988). Precipitation is distributed in a bimodal pattern with two alternate wet and dry seasons. The $\mathrm{Gu}$ season is the major rainy season lasting from April to June, followed by the minor Hagai dry season (July September). The Der season follows the Hagai and is a minor rainy season lasting from October to December, followed by the major Jilaal dry season from January through March. Characteristics of the rainfall pattern in southern somalia include scarcity, poor distribution, variability in the onset of the wet season and high variability in the amount of precipitation from year to year. This results in a drought recurrence interval of every four to five years (Handulle and Gay, 1987). Average annual temperature for the area is $290 \mathrm{C}$ ranging from 230 to $310 \mathrm{C}$. The relative humidity is uniformly high at approximately 80\%, except during the Jilaal dry season when it averages about 75\% (TAMS, 1986). Potential evaporation in the interior of southern Somalia is in excess of $2,500 \mathrm{~mm} /$ year, where it greatly exceeds annual precipitation. Soil moisture deficits in the interior prevail for most of the year and vegetative growth is highly seasonal. The length of the growing season and the severity of the soil moisture deficit are the primary factors determining range productivity in southern somalia (LRDC, 1985).

The soils of the project area are primarily vertisols. Textures are very heavy with up to 85\% clay, a high proportion of which are expanding clays (TAMS, 1986). The fineness of the soil pores causes soil moisture to be held in high tensions, with relatively little available to plants without irrigation. The project site is very gently to gently undulating, with an overall slope to the north (TAMS, 1986).

The Shabelle river receives $90 \%$ of its discharge from a catchment of approximately $300,000 \mathrm{~km} 2$ in the eastern highlands 
of Ethiopia at elevations exceeding 2,000 m (TAMS, 1986). The flow pattern is seasonal and torrential with high flows of short duration occurring in April, and longer duration flows occurring from August to December. The year to year flow variation is considerable, with an increasing tendency for the river to dry up in the lower reaches in the Jilaal (LRDC, 1985). Precipitation in and around the project area contributes very little to river flows, as the riverbanks are higher than the surrounding floodplain (TAMS, 1986). River water quality varies throughout the year with salinity crests occurring at the onset of the Gu wet season. With continuing irrigation development along the Shabelle, serious seasonal water shortages are being experienced (LRDC, 1985).

\section{Land Use}

The study area is part of a larger irrigation complex (Figure 2) put into operation by Italian colonists in the 1920s and $1930 \mathrm{~s}$ as a way to generate income for the colonial administration. The owners of the Italian plantations or "aziendas" (represented by rectangles of varying size in Figure 2) left in the 1960s, and smallholder irrigated agriculture has since become the dominant form of cultivation in much of the area. Following the organizational and social upheaval that accompanied the departure of the Italians, the irrigation infrastructure and management deteriorated considerably. Presently there is stiff competition for irrigation water among and between small and large farmers, and water allocation is relatively uncoordinated. Large farmer and plantation areas are present in a corridor along the river and the primary canals where access to water is relatively secure. Smallholder areas are further away from the river, and are more variably irrigated. The population of the small farmer area is relatively high, with the land per person being approximately $0.3 \mathrm{ha} /$ person. Small farmer water allocation takes place in a complex mixture of relationships and arrangements that are connected with numerous off-farm activities. Average farm size (several parcels may comprise one farm) is 2.24 ha. Small holder subsistence farms make up about $60 \%$ of the study area. The remaining area is divided among large farms and plantations. Present cropping patterns for the small farmers in the study area are dominated by maize (Zea mays) and sesame (Sesamum indicum) cultivated primarily as subsistence crops. Vegetables and other minor crops are grown only on a limited scale. Maize is cultivated primarily in the Gu season, while sesame is the 
dominant crop in the Der season. The little maize that is grown in the Der is dependent on available irrigation. Both the maize and sesame crop residue is cut and stacked as part of the harvesting process, in order to get it out of the way for the next season's cultivation, and to prevent livestock from trampling the field as they forage.

The production of fodder crops does not take place on the scheme. Nor does it presently appear feasible. Pastoralists are usually able to obtain freely what crop residue is available in the dry season. If subsistence farmers were to grow fodder crops in a good rainfall year, when plenty of free crop residue is available and fewer transhumant livestock arrive in the irrigated area anyway, the farmer would receive little or no money for his crop. This is a risk that subsistence farmers are unwilling to take. Large farms and plantations do not produce fodder crops for the same reasons. Government subsidy of fodder crops would entail the construction and maintenance of storage facilities, and a long term commitment for purchase and transport of the fodder harvested. While such an arrangement would be valuable for both farm and transhumant livestock in drought years, the government of any developing country burdened by external debts, and pursuing agendas of greater priority, would not be able to afford to subsidize fodder crops over the long term. International donors and development agencies likewise cannot be expected to support such an endeavor given the nature of their operational focus.

\section{Socioeconomic}

Livestock production is the primary economic activity in Somalia, comprising approximately 50\% of the gross domestic product and more than 80\% of export revenue. About 55\% of the national population participates in nomadic pastoralism, while $80 \%$ of the population is engaged in livestock raising of some kind (Handulle and Gay, 1987). The small farmers in the study area fall within the definition of subsistence producers according to Massey (1987).

The majority of the small farmers with land in the study area reside in the settlement of Shalambood (approximately 22,400 inhabitants, Figure 2) while smaller numbers live in the nearby villages of Gandow and Buffow. All three of these settlements are situated on the southeastern edge of the scheme. And while there are smaller villages in the study area, it is rare that a small farmer will actually live on the farm. 


\section{Livestock and Livestock Movements}

The pastoral systems of Somalia are made up of cattle, camels, sheep, and goats. The cattle of southern somalia are mainly of the East African Shorthorn (thoracic humped) Zebu (EASZ) type. However some cattle show traits of crosses between the EASZ and the other long horned thoracic humped Zebu

crossbreed cattle typical of Ethiopia and northwest Somalia. In the EASz type three local breeds are represented, the Cassara, Dawara, and Boran. The crossbred cattle are recognized as the local Surqa breed. Somali camels are of only one type, the single humped dromedary. There are however breed variations associated major geographical areassouthern somalia, the coast, northern Somalia, and the mountains in the extreme north of the country. Two types of goats are present. The short Eared East African type (the most predominant) and the Arbed type. Sheep are uniformly of the Somali Blackhead type (LRDC, 1985).

Transhumant livestock are found in the Lower Shabelle region (Figure 1) from the end of the Hagai dry season to the end of the Jilaal dry season, until the Gu rains begin. Dry season livestock migrations into the shabelle river basin just inland from Merca (which includes the study site) result in one of the highest livestock densities in the country (Figure 3) (RMR, 1984). During the Gu season these herds disperse north and northwest into the Bay region in order to take advantage of the surface water in the interior and avoid tsetse fly infestations which occur along the river in the wet seasons (Salisbury, 1988). As the surface water begins to dry up the herds concentrate around wars (manmade shallow catchment ponds) and wells which are used until late in the Hagai season. When these begin to dry and forage becomes scarce, the herds are moved back into the Lower shabelle region. The first herds to return to the region usually belong to the agropastoralists who are settled along the shabelle river. Livestock belonging to nomads do not arrive in large numbers until late in the Der season. Herds arriving in the region during the Hagai season are kept in the bush, 15 to $20 \mathrm{~km}$ away from the river, because the $\mathrm{Gu}$ season crops cut off river access. Animals begin to move into the irrigated area after the Gu harvest, but do not arrive in the study site in large numbers until the Jilaal dry season (Salisbury, 1988). Livestock spend the Jilaal concentrated on croplands close to the river where they feed on crop residues and riverine grassland. As the dry season continues this concentration increases, and in severe droughts livestock from other areas can be drawn to the irrigated area to compete for 
crop residues (RMR, 1984). Figure 3 shows the livestock movements into the area prior to and during the dry season. The numbers of livestock owned by the resident agriculturalist population which are kept in the study area varies with the season and the severity of forage and water shortages in the interior. In the wet seasons of good rainfall years, much of this livestock is kept off-scheme in the interior where arrangements are made with nomadic relatives or others to graze and water the herds in a transhumant fashion. However in years of greater water and forage scarcity, these animals may spend part or all of the wet season on-scheme where their owners are able to ensure forage and water supplies. This means that less forage will be available to nomadic herds when they arrive at the onset of the dry season.

\section{Data Acquisition}

\section{METHODS}

The data for this study were collected during 18 months of fieldwork, and consisted of key informant interviews, questionnaire surveys, and parcel measurements.

Three formal questionnaire surveys were carried out targeting three different groups: small farmers (less than 25 ha.), large farmers (25 ha and above), and agro-pastoralists. The small farmer survey consisted of three rounds of questionnaires given to 114 randomly selected participants, and focused on a wide variety of subjects. These included: demographics, land use, agricultural practices, access to water, livestock numbers and types, livestock forage and water

locations and arrangements, and a range of socioeconomic topics. The large farmer survey was made up of 30 nonrandomly selected participants who were interviewed once and were asked for much of the same information. The agro-pastoralist survey comprised 123 nonrandomly selected interviews with small farmers who also owned livestock and were familiar with seasonal fodder sources and fodder requirements for livestock. The agro-pastoralist survey was carried out solely for the purpose of determining the relationship between the different types and states of land present in the study area and the length of time that livestock are able to live off this land. Of interest was the livestock carrying capacity of land under fallow, maize and sesame residue, riverine grassland, and previous cultivation in good, average, and poor precipitation/irrigation years.

Parcel measurements were obtained for all of the randomly selected small farmers in the study in order to accurately 
determine area. Because all of the area owned by large farmers is registered and therefore had to be surveyed, farmer statements of these farm sizes were taken to be relatively accurate.

\section{Standard Stock Units (SSU)}

Conversion of livestock quantities into standard stock units (SSU) was accomplished following Field (1980) using Somali specific breeds, herd age structure, feeding habits, and liveweights. For somali conditions the standard stock unit is a mature bovine with a liveweight of $450 \mathrm{~kg}$ that consumes 4,100 kg of dry matter per year. In this framework one SSU is equivalent to two camels or cattle, 20 sheep or goats, or 5 donkeys.

\section{Initial Statistics}

Initial statistics for the small and large farm surveys were calculated using SPSS. These included:

1. total standard stock units owned, and the grazing and watering locations of livestock belonging to small

farmers resident in the study area who both do and do not allow free grazing in good, average, and poor Gu, Der, and Jilaal seasons;

2. small and large farmer ownership of livestock over time;

3. determination of small farmers as subsistence agriculturalists using crop production figures;

4. fodder and grazing rights transactions for small farmers who do and do not allow free grazing during the Jilaal;

5. total seasonal hectares and proportions of the sample area under the various land categories including: crop types (monocrop and intercrop), fallow, previously cultivated, and permanent grazing land for small and large farmers;

6. the proportion of good, average, and poor rainfall years;

7. when transhumant herds arrive on scheme in good, average, and poor precipitation years;

Responses to the agro-pastoralist survey were averaged in order to determine the time that livestock could be maintained on land in each of the categories in all seasons of good, average, and poor water years. Livestock values were then converted to SSU.

\section{Determination of Study Site SSU Carrying Capacity}


In order to determine the livestock carrying capacity for the different land uses (in different states in different seasons of the year, and in good, average, and poor water years) land was grouped into five categories: 1. land under maize cultivation; 2. land under sesame cultivation; 3. previously cultivated land (applicable only in the Jilaal season and includes all land previously cultivated irrespective of crop); 4. fallow land, and 5. areas under riverine grassland. The grassland areas comprise narrow strips (approximately $50 \mathrm{~m}$ wide) that occur along major canals, some parts of the old river channel, and in abandoned reservoirs as a result of seepage, or a locally high water table.

The total study area under each of these categories in each season was obtained by extrapolating from the category areas in the random sample. It is possible for a single piece of land to belong to several different categories over the course of the year, producing different livestock carrying capacities depending on the season and the use. And while carrying capacity was calculated on a seasonal basis, the carrying capacity in any one season depends on the land use in the previous as well as the present season. For example, if a parcel is cultivated with maize or sesame in the Der season, the crop residue will not be available until harvest at the end of the season. Then in the following Jilaal the carrying capacity for that parcel would be the carrying capacity of the crop residue from the Der season cultivation (cut and stacked in the corner of the parcel) plus the carrying capacity of the parcel itself in the category of previously cultivated. While the carrying capacity of the previously cultivated category is the lowest of any category, it is still significant due to the inefficiency of hand weeding, such that the noncrop vegetation present after harvest is able to support some livestock.

Calculation of carrying capacity for the crop residue categories in good, average, and poor water years was accomplished following equations 1 and 2. The unit used for the quantity of maize crop residue is known locally by the term bal, and the local unit ambul was used for sesame.

\section{Eq. \#1. Qsi $=(\mathrm{Xi} / \mathrm{Rw}) / 3$}

where: Qsi = the monthly quantity of crop residue units available in season $s$ in land category i (number of maize bals or sesame ambuls);

$\mathrm{Xi}=$ the total area (ha.) under category $i$;

$\mathrm{Rw}_{\mathrm{w}}=$ the area producing a single unit $\underline{\text { bals }}$ or 
where

$$
\text { ambuls) of crop residue in water year } \mathrm{w} \text {, }
$$

$$
3=\begin{aligned}
& \text { w is defined as good, average, or poor } \\
& \text { number of months per season, for all seasons. }
\end{aligned}
$$

Eq. \#2. $\quad \mathrm{Csi}=\mathrm{SSUi} \star \mathrm{Qsi}$

$$
\begin{aligned}
\text { where: } \mathrm{Csi}= & \text { the carrying capacity for SSU in season } \mathrm{s} \text { on } \\
& \text { land category } i \text {; } \\
\mathrm{SSUi}= & \text { the number of SSU that can live off a single } \\
& \text { unit of crop remnant of category } i \text { for one } \\
& \text { month; } \\
\mathrm{Qsi}= & \text { defined in equation } 1 .
\end{aligned}
$$

Thus the seasonal carrying capacity (3 months) was obtained by dividing the total land area (Xi in equation 1) in each of the crop categories where fodder access is allowed, by the area producing a single unit of crop residue in good, average, and poor water years ( $\mathrm{Rw}$ in equation 1 ). This gave the total quantity of crop residue produced in a year for category i. This quantity was then divided by 3 months to get the quantity available on a per season basis (equation 1). Total area under each category was obtained from parcel measurements of small farmer's land in the random survey. The number of forage units produced (for crop residue), in good, average, and poor years was obtained from the agro-pastoralist survey. The final conversion to carrying capacity was then obtained by equation 2, where the number of livestock units that could live off a single unit of crop residue for one month (SSUi) was multiplied by the total number of units of residue (Qsi). This gave a sustainable number of SSU per season (Csi). Carrying capacity was calculated on a seasonal basis because season determines availability. For the categories of fallow, previously cultivated, and riverine grassland, the carrying capacity was calculated using equation 3:

Eq. \#3. $\mathrm{Csi}=(\mathrm{Xi} * \mathrm{SSUiw}) / 3$

where: $\mathrm{Csi}=$ defined in equation 2;

$\mathrm{Xi}=$ defined in equation 1 ;

SSUiw $=$ the number of SSU sustainable on one hectare of land category $i$ in water year w;

$3=$ number of months per season.

The total area available under the above mentioned categories 
(Xi) was multiplied by the number of SSU sustainable on one hectare of the category in years of varying water quantity (SSiw), in order to obtain the total number of SSU sustainable. This value was then used to obtain the quantity of SSU sustainable per month for the season (Csi).

\section{Comparison of Sustainable and Observed SSU}

Comparison of observed SSU with the calculated carrying capacity was carried out in order to determine if the livestock carrying capacity of the scheme could support the quantity of livestock actually present (observed SSU) during dry seasons of varying severity. This was accomplished following equation 4:

Eq. \#4. $\mathrm{Ks}=(\boldsymbol{\Sigma} \mathrm{Cs} i)-\mathrm{Os}$

where: $\mathrm{KS}=$ the number of observed SSU not sustained in season $s$ (if a negative number), or the extra number of SSU which could be sustained (if a positive number);

$(\Sigma \mathrm{Csi})=$ the summation of all crop/land category carrying capacities i which are available in season $s$;

Os = the observed number of $\mathrm{SSU}$ in season $\mathrm{s}$;

By summing the sustainable carrying capacities for each of the land categories which are available in a particular season ( $\Sigma$ Csi), then subtracting from this value the observed number of SSU in the study area at that time (Os), the number of SSUs not sustained, or the extra SSUs which could be sustained in this season were determined (Ks).

Onscheme wet season SSU densities from the small farmer questionnaires correspond with densities estimated from overflights of the area by Resource Management and Research (RMR) (1984). Overflights were undertaken in both wet and dry seasons, facilitating the estimation of dry season SSU densities on scheme. Small and large farmer questionnaire-derived estimates of SSU presence in the study area were used for the Gu, Hagai, and Der seasons, allowing a more detailed analysis of onscheme SSU numbers in these seasons. Der season observed SSU values were used for the Hagai season because sampling did not take place during the Hagai. However Der SSU estimates are higher than in the Hagai (Salisbury, 1988) thus erring on the conservative side. In the Jilaal, RMR's (1984) estimates of dry season SSU densities for the area (which includes large and small farmer areas of the scheme) for an average water year were 
used for each of the water quality years (good as well as poor) as these were the only data available. The SSUs owned by resident farmers on-scheme who did not allow fodder access on their land were excluded from the calculations, as it was assumed that their land is used to sustain their own livestock. Large farmer SSU quantities were constant for Gu, Hagai, and Der of all water quality years in the calculations because large farmers do not usually send their livestock to the interior in wet seasons as small farmers do. The only change in SSU numbers in the large farmer area then is during the Jilaal when RMR's (1984) livestock density estimates for the whole area were used to estimate the dry season increase in SSU numbers in the large farmer areas.

\section{Calculation of Irrigated Land Allocation for the Integration of Transhumant Herds in the Dry Season}

The area under present land use that is needed to accommodate the transhumant herds that arrive in the study area in the dry season was calculated using carrying capacities for livestock in years of varying dry season severity. These carrying capacities were used to obtain ratios of irrigated land optimally allocated to three broad land use classes: plantation agriculture, large producers, and small farmers. Transhumant livestock not supported in the large farmer areas must go to the small farmer areas, which increases the SSU density there. Plantation agriculture (such as bananas) exclude $100 \%$ of the transhumant livestock which would have occupied the area otherwise. This livestock must also go to the small farmer areas. Thus an important part of the calculation of the needed land area to absorb the transhumant herds in the dry season is the accounting for the livestock that are excluded from plantation and large farmer areas.

Determination of the area of small farmer land that would be needed under present land use practices in order to sustain the observed SSU density in the Jilaal was made following equation $5:$

Eq. \# 5 .

$\mathrm{NHS}=[(\mathrm{SFOS} / \mathrm{SFA})+(\mathrm{LFKS} / \mathrm{LFA})+\mathrm{P}] /[(\Sigma \mathrm{Ci}) \mathrm{s} / \mathrm{SFA}]$ where: NHs = Number of hectares of small farmer area needed for

every 1 hectare of large farmer area and 1

hectare of plantation area;

$\mathrm{SFOS}=$ the total observed number of SSU in the small farmer area in season s; 


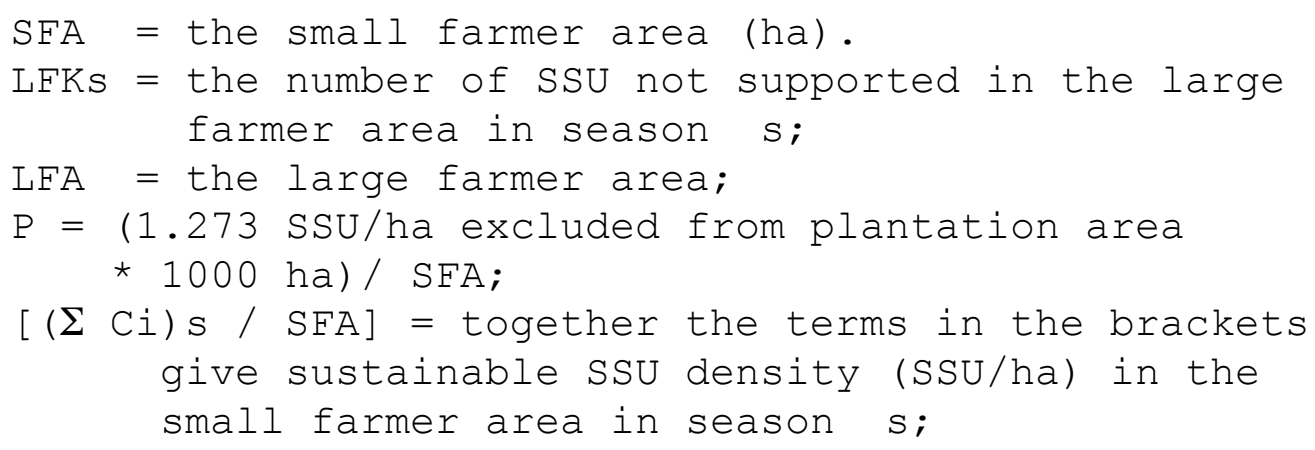

Thus the total observed SSU density from the small farmer area (SFOs / SFA) and from the large farmer area not supported there (LFKS / LFA) were summed together with the density from the plantation area to obtain an SSU per hectare total density which ends up in the small farmer area. This density is divided by the small farmer area sustainable density [( $\boldsymbol{C} \mathrm{Ci}) \mathrm{s} / \mathrm{SFA}]$ to give the number of small farmer hectares needed for every 1 hectare of large farmer area and 1 hectare of plantation area in the scheme, in order to maintain the observed SSU which arrive in the small farmer area in the dry season.

\section{RESULTS}

The development of irrigated agriculture in arid and semiarid Africa concentrates four separate land use interests, each with very specific and often conflicting agricultural arrangements, goals, and agendas, onto a single geographic area. Those engaged in plantation agriculture usually have the backing of the national government and are engaged in the production of cash crops for export in order to gain hard currency. Large farmers not growing export crops are most often engaged in the production of much needed food for the rapidly expanding urban centers. The small, or subsistence farmers are the most populous group and seek to provide for themselves and grow occasional surpluses to be sold in local or urban markets. The nomadic pastoralists are interested in getting through the dry season and occasional droughts with as little loss to their herds as possible. These interest groups define the variables which, together with season and time, are responsible for the livestock carrying capacity in the irrigated area.

The five variables which interact each other to govern carrying capacity and a livestock presence in the study area, include: 1. land area, in different categories, each of which can be in one of three possible states; 2. livestock numbers, in varying locations and varying quantities for different lengths 
of time; 3. season, which changes throughout the year and between years for a total of nine different seasonal states; 4 . quantity of fodder available, which changes with season, precipitation, irrigation, land use, farm owner, and livestock; and 5. time. The primary objective of this study is to outline in quantitative terms, the interaction of these variables under changing conditions in order to explore the proportional area requirements needed for integration of nomadic herds and irrigated agriculture. The variable "time" drives the land categories through different seasons of varying water quantity. The quantity of livestock in a specific location for a specific length of time are dependent on seasonal state and quantity of fodder.

The categories available to be utilized for forage in the Gu season include only riverine grassland and fallow land, as all other land is under cultivation. For the Hagai season available forage sources include fodder left over from the Gu season, plus maize and sesame crop residue from the Gu season harvest, as well as Hagai season grassland areas. Land fallowed in the Gu is fully accounted for in the Gu, and thus is not available in the Hagai. Der season forage sources include fodder left over from the Hagai, and Der season fallow and grassland areas. In the Jilaal, maize and sesame crop residue produced in the Der season, plus the categories of previously cultivated, (which includes Der fallow land), grassland, and any fodder left over from the Der season are available. No fodder left over from the Jilaal season is carried over to the Gu. Not considered in the calculations of the fodder left over from one season and used in the next are rates of biomass decay or the quantity consumed by insects. Thus these are intended as approximate estimates of carrying capacity.

Table 1 compares the percentage of total land area open to transhumant herds under each of the land categories, for large and small farmers. For all categories except grassland, large farmers allow much less free grazing on their land than do small farmers. This is because large farmers practice more intensive agriculture and are not as involved in exchange relationships with livestock owners. For the maize and sesame categories, small farmers allow free grazing on $81 \%$ and $70 \%$ more land, respectively than do large farmers. For the fallow land category, small farmers allow free grazing on 43\% more land. In previously cultivated areas, 21\% more land is available in the small farmer area. However for riverine grassland, large farmers have $62 \%$ more area open for free grazing than do small 
farmers.

Tables 2 and 3 present the calculated SSU carrying capacity for the small and large farmer areas respectively in good, average, and poor water years for all seasons. These numbers represent the values for Csi in equations 2 and 3 . For all categories except "previously cultivated" the SSU carrying capacities range between 49\% and 58\% less in a poor year compared to a good year. The previously cultivated category expressed a poor year carrying capacity that was 78\% less than in a good year, meaning that as a fodder source the previously cultivated category is most vulnerable to severe dry seasons and drought. The fallow and grassland categories are less vulnerable, the carrying capacities of these being reduced by 55\% and 58\% respectively, in poor years. The two crop categories (maize and sesame) are least vulnerable as a fodder source, the carrying capacities of both are reduced by 49\% and $50 \%$ respectively from good to poor years.

Table 4 shows the quantity of SSUs in the study area which are not supported (negative numbers), as well as the additional numbers of SSU which could be supported (positive numbers). The numbers for the small and large farmer areas represent values for KS in equation 4. Significant differences can be noted between good, average, and poor years for the small farmer area. In a good Jilaal, 10,220 more SSUs can be supported than in an average Jilaal, and 12,800 more can be supported than in a poor Jilaal. The values for SSUs not supported in large farmer areas (Table 4) are higher overall, reflecting the large area under permanent agriculture and thus unaccessible for livestock grazing. The SSUs not supported in the large farmer area then seek fodder access in the small farmer area. This quantity, in addition to the SSUs already in the small farmer area plus the SSUs excluded from the plantation area, represents the total number of SSUs which end up in the small farmer area in the Jilaal.

Table 5 shows the small farmer area (hectares) necessary for every one hectare under plantation and one hectare of large farm agriculture in order to absorb the number of livestock in the study area in all seasons, in years of varying water quantity. These are values for NHs in equation 5. The area needed in an average Jilaal is 2.8 times that needed in a good year, and in a poor Jilaal the area needed is 4.6 times greater than in a good year.

The impact of the resident livestock (that owned by the agriculturalists) on fodder supplies can be considerable. In 
poorer water years, more farmers keep their livestock on-scheme in the wet seasons. This reduces the forage available later for transhumant herds in a year when fodder production is already less, and greater numbers of livestock will be arriving earlier in the study site in response to the poor forage availability in the interior. Equation 4, building on equations 1 - 3, incorporates this into a calculation using season specific observed SSUs and carrying capacities.

\section{DISCUSSION}

The values in Table 5 represent a continuum encompassing the existing mosaic of land use and some of the climatic variability inherent in the functioning of the area as a dry season forage source for transhumant herds. If expanded, the continuum would include increasingly large areas reflecting the need for more land to sustain nomadic herds during dry years of increasing severity. Maintaining transhumant herds on-scheme during most of the good, average, and poor years, means that overgrazing in other areas of the migratory route would not occur during this time. Thus when a drought or a string of poor years does occur, the pastoralists, their herds, and the range will be less vulnerable.

In the design of an irrigation scheme a realistic point along this continuum must be chosen which will serve to maintain most of the transhumant herds in most years. In this case the value for an average Jilaal (1.17 ha) might be considered optimal. A good year occurs three years out of ten, an average year 3.2 years out of ten, and a poor year 4 years out of ten. Thus if a scheme were designed for an average water year it would absorb transhumant herds 6.2 years out of ten good plus average). Some stress in some years with respect to available dry season forage is perhaps desirable in order to maintain relatively constant livestock numbers in the long term. If all nomadic herds visiting the study site were sustained even in poor years, the result might be large increases in herd size by nomads, similar to what occurs during a series of good rainfall years.

The differences in the vulnerability of fodder sources in poor years has design implications. The reduction in carrying capacity of the grassland category from good to poor years in the small farmer area is 58\%, compared to 49\% and 50\% for the maize and sesame categories, respectively. Further research may indicate that greater priority should be given to optimal and reliable water distribution to small farmer crop production in 
irrigation schemes, than to providing and enforcing the maintenance of grassland commons for the grazing of transhumant livestock, given that access to crop residue is not denied. While substantial increases in the production of crop residues might be realized through the utilization of agricultural inputs, it would be unwise to include such increases in the calculation of the area needed to sustain transhumant herds because this would assume that such inputs will always be readily available, at a price that all small farmers could always afford, and that it is properly applied in a uniform manner over the entire small farmer area. A potential development however, could be that later if/when the area develops and a part of the revenues generated by the success of the various production systems is put back into the scheme on a continual basis, other arrangements may be possible such as the subsidy, production, and storage of fodder crops. This may then allow plantation and/or intensive agriculture to expand, if such was a priority.

From a land tenure perspective, having adequate free forage available onscheme for livestock in most years may decrease the monetary value of crop residue and thereby encourage a continued communal land tenure arrangement by small farmers in the Jilaal, because little would be gained by maintaining private tenure over crop residue and other grazing sites for purposes of monetary gain. This might encourage those that presently do not allow free grazing in the Jilaal to allow it, further supporting dry season communal tenure. Ultimately this may result in less dry season area needed to support transhumant herds.

Presently $61 \%$ of the small farmers in the sample own livestock. However there has been a 36\% reduction in the number of livestock owned between when small farmers (as a group) first started farming and the present. Should this trend continue, it would also mean more forage for transhumant herds, and an additional reinforcement for communal tenure arrangements in the Jilaal. Allowing pastoralist access and utilization of crop residue resources on the shalambood scheme demonstrates that irrigated agriculture in Africa can play a role in supporting both residential and transhumant populations of livestock. Such an arrangement, especially if legally reinforced, would allow agricultural development while not contributing to overgrazing and degradation elsewhere.

Acknowledgments

This research was part of a Land Tenure Center study on 
land and water resource issues in southern Somalia. I would like to thank the Somali Ministry of Agriculture, and USAID for their support, and Michael Roth for reading and commenting on earlier drafts of this manuscript.

\section{Literature Cited}

Bennett, J.W. (1984). Political ecology and development projects affecting pastoralist peoples in east Africa. Land Tenure Center Research Paper No. 80. Land Tenure Center, Madison, Wisconsin.

Box, T. (1971). Nomadism and land use in Somalia. Economic Development and Cultural Change 19: 222228.

Box, T. (1968). Range resources of Somalia. Journal of Range

Management 21: 388392 .

Breman, H., Cisse, A.M., Djiteye, M.A., and Elberse, W.Th. (1979). Pasture dynamics and forage availability in the Sahel. Israel Journal of Botany 28: 227251.

Campbell, D.J. (1981). Landuse competition at the margins of the rangelands: an issue in development strategies for semiarid areas. In Norcliffe, G., and Pinfold, T. (eds.), Planning African Development, Westview Press, Boulder, Colorado.

Chatterton, B., and Chatterton, L. (1984). Alleviating land degradation and increasing cereal and livestock production in north Africa and the Middle East using annual medicago pasture. Agriculture, Ecosystems and Development 11: 117129 .

Darling, F.F., and Farvar, M.A. (1972). Ecological Consequences of Sedentarization of Nomads. In Farvar, M.T. and Milton J.P. (eds.), The Careless technology: Ecology and International Development. The Natural History Press, Garden City, New York.

Davis, R.K. (1971). Some issues in the evolution, organization and operation of group ranches in Kenya. East African Journal of Rural Development 4: 2233.

Field, D.I. (1980). Grazing Capacity of Rangelands. Technical Note No. 2, Somali Range Bulletin 11, National Range Agency, Mogadishu, Somalia. 
Frantz, C. (1975). Contraction and expansion in Nigerian bovine pastoralism. In Monad, T. (ed.), Pastoralsim in Tropical Africa. International African Institute, Oxford University Press, pp. 338353 .

Gulliver, P.H. (1975). Nomadic movements: causes and implications. In Monod, T. (ed.), Pastoralism in Tropical Africa. International African Instutite, Oxford University Press.

Handulle, A.A., and Gay, C.W. (1987). Development and traditional development in Somalia. Nomadic Peoples 24: 3643.

Johnson, D.L. (1986). Resource use in dry places: present status and potential solutions. In Kates, R.W., and Burton, I. (eds.), Geography, Resources and Environment II: Themes from the Work of Gilbert $F$. White. University of Chicago Press, Chicago.

Krader, L. (1959). The ecology of nomadic pastoralism. International Social Science Journal 11: 499510.

Lamprey, H.F. (1983). Pastoralism yesterday and today: the overgrazing problem. In Bourliere, F. (ed.), Tropical Savannas: Ecosystems of the World. Elsevier, Amsterdam.

Land Resources Development Center (LRDC) (1985). Land Use in TsetseAffected Areas of Southern Somalia. Tolworth Tower, Tolworth, Surbiton, KT6 7DY, UK.

Lewis, I.M. (1975). Abaar: the Somali drought. International African Institute, Emergency Report 1, Oxford University Press.

Little, P.D. (1984). Critical socioeconomic variables in African pastoral livestock development: toward a comparative framework. In Simpson, J.R., and Evangelou, P. (eds.), Livestock Development in Subsaharan Africa: Constraints, Prospects, Policy. Westview Press, Boulder, Colorado.

Massey, G. (1987). Subsistence and Change: Lessons of Agropastoralism in Somalia. Westview Press, Boulder, Colorado.

McCabe, J.T. (1987). Drought and recovery: livestock dynamics among the Ngisonyoka of Kenya. Human Ecology 15: 371389. 
Ministry of Agriculture Meterological Service (1988). Precipitation. Ministry of Agriculture, Modadishu.

Mohamed, M.A. (1981). Portrait of a dry region. Unasylva 33: $2-7$.

Oba, G. (1985). Perception of environment among Kenyan pastoralists: implications for development. Nomadic Peoples 19: 3357 .

Otterman, J. (1974). Baring highalbedo soils by overgrazing: a hypothesized desertification mechanism. Science 186: 531533.

Reck, R.A. (1989). The albedo effect. Scientific American, September.

Resource Management and Research (RMR) (1984). Somali Democratic Republic Southern Rangelands Survey. Vol 4, Part 1, 16B West Central St., London W.C.1.

Riddell, J.C. (1982). Land tenure issues in west African livestock and range development projects. Land Tenure Center Research Paper No. 77. Land Tenure Center, Madison, Wisconsin.

Riney, T. (1979). Wildlife vs. nomadic stocks. Unasylva 31 : $15-20$.

Ripley, E.A. (1976). Drought in the Sahara: insufficient biogeophysical feedback? Science 191: 100102 .

Salisbury, L. (1988). The role of livestock in the Lower Shabelle. United States Agency for International Development Somalia Mission. Mogadishu.

Salzman, P.C. (1986). Shrinking pasture for Rajasthani pastoralists. Nomadic Peoples 20: 4960.

Sandford, S. (1983). Management of Pastoral Development in the Third World. John Wiley and Sons, New York.

Sanford, S. (1982). Pastoral strategies and desertification: 
opportunism and conservation in dry lands. In Spooner, B., and Mann, H.S. (eds.), Desertification and Development: Dryland Ecology in a Social Perspective, Academic Press, London.

Sanford, S. (1976). Pastoralism under pressure. Review no. 2, Overseas Development Institute, London, pp. 45-68.

Scudder, T. (1989). River basin projects in Africa. Environment $31: 432$.

Speth, J.G. (1985). Arid lands in the global picture. In Whitehead E.E., Hutchinson, C.F., Timmermann, B.N., and Varady, R.G. (eds.), Arid Lands: Today and Tomorrow. Westview Press, Boulder, Colorado.

Stiles, D.N. (1983). Desertification and pastoral development in northern Kenya. Nomadic Peoples 13: 114.

Swift, J. (1977). Sahelian pastoralists: underdevelopment, desertification, and famine. Annual Review of Anthropology 6: 457478 .

Talbot, L.M. (1972). Ecological consequences of rangeland development in Masailand, east Africa. In Farvar, M.T., and Milton, J.P. (eds.), The Careless Technology: Ecology and International Development, The Natural History Press, Garden City, New York.

Tippets Abbett McCarthy Stratton (TAMS) (1986). Genale Irrigation Rehabilitation Project Feasability Study, Annex I. Natural and Human Resources, 655 Third Ave., New York, New York.

Toulmin, C. (1985). Livestock losses and postdrought rehabilitation in subSaharan Africa. LPU Working Paper No. 9, International Livestock Center for Africa, Addis Ababa.

Walsh, J. (1984). Sahel will suffer even if rains come. Science $224: 467-471$.

Western, D. (1975). Water availability and its influence on the structure and dynamics of a savannah large mammal community. East African Wildlife Journal 13: 265286. 
Table 1. Percent of Total Area Available to Transhumant Herds for Large and Small Farmers

Small farmer area: 5133.0 ha. Large farmer area: 3126.7

$\begin{array}{lcr}\text { Category } & \text { Small Farmers } & \text { Large } \\ \left(\frac{\circ}{0}\right) * & & \\ \text { Maize } & 63.75 & 12.03 \\ \text { Sesame } & 38.34 & 11.43 \\ \text { Fallow/Idle } & 29.0 & 16.66 \\ \text { Prev. Cultivated** } & 66.48 & 20.47 \\ \text { Grassland } & 2.0 & 5.25\end{array}$

* Spatial double accounting has taken place in order to realistically account for all forage available.

** Jilaal season only.

Table 2. Calculated Fodder Carrying Capacity for the Small

Farmer Area.

(Units in SSUs sustainable for the season

in which the fodder is produced*) 


\section{Good Year}

\begin{tabular}{|c|c|c|c|c|}
\hline Category & $\underline{\mathrm{Gu}}$ & Hagai & $\underline{\text { Der }}$ & Jilaal \\
\hline$\overline{\text { Maize }}$ & $73 \overline{64} .4$ & & $\overline{816.2}$ & \\
\hline Sesame & 637.2 & & 1436.5 & \\
\hline Fallow/Idle & 786.3 & & 4256.54 & \\
\hline Prev. Cult. & & & & 2911.4 \\
\hline Grassland & 39.0 & 39.0 & 39.0 & 39.0 \\
\hline
\end{tabular}

\section{Average Year}

\section{Category}

Maize

Sesame

Fallow/Idle

Prev. Cult.

Grassland

\section{Category}

Maize

Sesame

Fallow/Idle

Prev. Cult.

Grassland

$\frac{\mathrm{Gu}}{43} \cdot 9$
477.9
569.4
27.7

$\mathrm{Gu}$ $37 \overline{21} .0$

318.6

357.4

16.4
Hagai

\begin{tabular}{rr}
\multicolumn{1}{c}{$\begin{array}{r}\text { Der } \\
547.9\end{array}$} & \\
1077.4 & \\
308.3 & \\
27.7 & 1771.6 \\
& 27.7
\end{tabular}

\section{Poor Year}

Hagai

$$
\begin{aligned}
& \frac{\text { Der }}{412.7} \\
& 718.3 \\
& 1929.1
\end{aligned}
$$

$\underline{\text { Jilaal }}$

16.4
635.2

16.4

*The Gu and Der season maize and sesame production are available in the subsequent Hagai and Der seasons respectively, and not in the season in which they were produced.

Table 3. Calculated Fodder Carrying Capacity for the Large

Farmer Area.

(Units in SSUs sustainable for the season

in which the fodder is produced*) 


\section{Category}

Maize

Sesame

Fallow/Idle

Prev. Cult.

Grassland

\section{Category}

Maize

Sesame

Fallow/Idle

Prev. Cult.

Grassland

\section{Category}

Maize

Sesame

Fallow/Idle

Prev. Cult.

Grassland

$\frac{\mathrm{Gu}}{914} \cdot 4$
3.2
440.2
65.7

$65 \cdot 7$

\section{Good Year}

Hagai

$\begin{array}{cl}\frac{\text { Der }}{26.3} & \text { Jilaal } \\ 373.6 & \\ 440.2 & 440.2 \\ 65.7 & 400.2 \\ & 65.7\end{array}$

Average Year

$\mathrm{Gu}$

613.9

Hagai

$\frac{\text { Der }}{17.3}$

280.2

319.0

319.0

319.0

243.9

46.6

46.6

46.6

\section{Poor Year}

$\underline{\mathrm{Gu}}$

$3 \overline{65} .8$

Hagai

Der Jilaal

1.5

199.6

199.6

13.3

186.8

199.6

199.6

87.5

27.6

27.6

27.6

*The Gu and Der season maize and sesame production are available in the subsequent Hagai and Der seasons respectively, and not in the season in which they were produced.

Table 4. Results of Comparison Between Observed SSU and Calculated SSU

Carrying Capacity for Small and Large Farmers (Units in additional SSU sustainable (if positive) or the number of observed SSU not supported (if negative)) 


\begin{tabular}{|c|c|c|c|}
\hline & \multicolumn{3}{|c|}{ Small Farmer Area } \\
\hline & Good yr. & Average yr. & Poor yr. \\
\hline $\mathrm{Gu}$ & 792.3 & 29.3 & -728.8 \\
\hline Hagai & 8797.6 & 4881.0 & 2895.8 \\
\hline Der & 13057.9 & 4619.3 & 3681.1 \\
\hline \multirow[t]{3}{*}{ Jilaal } & 11857.8 & 1640.7 & -939.5 \\
\hline & \multicolumn{3}{|c|}{ Large Farmer Area } \\
\hline & Good yr. & Average yr. & Poor yr. \\
\hline $\mathrm{Gu}$ & 370.6 & 230.4 & 92.1 \\
\hline Hagai & 1658.8 & 1076.9 & 551.4 \\
\hline Der & 2029.5 & 1307.3 & 643.5 \\
\hline Jilaal & -644.8 & -1765.5 & -2821.8 \\
\hline
\end{tabular}

Table 5. Hectares of Small Farmer Area Needed in Years of Varying Water Quantity for Every Hectare of Land Under Plantation and Large Farmer Agriculture

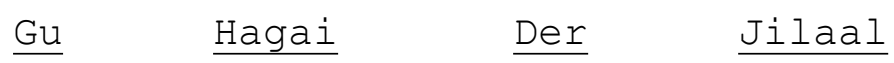

$\begin{array}{lllll}\text { Good yr. } & 1.58 & 0.15 & 0.10 & 0.46 \\ \text { Average yr. } & 3.08 & 0.34 & 0.36 & 1.17 \\ \text { Poor yr. } & 6.36 & 0.60 & 0.50 & 1.92\end{array}$

Figure Captions

Figure 1. Location of the Study Site in Southern Somalia 
Figure 2. The Study Site within the Irrigation Scheme

Figure 3. Dry Season Livestock Movements in Southern Somalia 